\title{
Understory plant species composition 30-50 years after clearcutting in southeastern Wyoming coniferous forests
}

\author{
Paul C. Selmants ${ }^{*}$, Dennis H. Knight \\ ${ }^{a}$ Department of Botany, University of Wyoming, Laramie, WY 82072, USA
}

Received 15 August 2002; received in revised form 18 October 2002; accepted 5 May 2003

\begin{abstract}
To evaluate the long-term effects of clearcutting and slash treatment on understory plant species composition in Rocky Mountain coniferous forests, we collected comparable data from 30- to 50-year-old post-harvest stands and adjacent mature (>100-year-old) stands that originated after wildfire. In general, plant species richness was higher in the post-harvest stands than in adjacent mature stands, due in large part to the presence of species that benefit from disturbance. Species composition in postharvest and mature stands was more similar in montane forests (2710-2805 m elevation) than in subalpine forests (2800-3164 m elevation), suggesting greater resilience of montane understories. Composition in post-harvest and mature stands was least similar when slash was piled and burned, and most similar when slash was lopped and scattered. Eighty-seven percent of the post-harvest stands had at least one exotic species, but total cover of exotic plant species in all post-harvest stands was $\leq 1 \%$. Exotic species were largely absent from mature forests. Our results suggest that understory species of low-elevation montane forests recover more quickly from disturbance than do those of subalpine forests, with slash treatment and species life history traits strongly influencing this recovery.
\end{abstract}

(C) 2003 Elsevier B.V. All rights reserved.

Keywords: Clearcut logging; Coniferous forests; Pinus contorta; Rocky Mountains; Slash treatment; Understory species composition; Vaccinium scoparium; Wyoming

\section{Introduction}

Sustainable forest management requires monitoring the effects of past management practices (Grumbine, 1994). While various studies have investigated understory plant succession after timber harvesting (Corns and LaRoi, 1976; Bormann and Likens, 1979; Stransky et al., 1986; Halpern, 1988, 1989;

\footnotetext{
* Corresponding author. Present address: School of Forestry and Merriam-Powell Center for Environmental Research, Northern Arizona University, Flagstaff, AZ 86011, USA.

Tel.: +1-928-523-1469; fax: +1-928-523-1080.

E-mail address: pcs4@dana.ucc.nau.edu (P.C. Selmants).
}

Schoonmaker and McKee, 1988; Halpern and Franklin, 1990; De Grandpre et al., 1993; Halpern and Spies, 1995; Gilliam et al., 1995; Roberts and Gilliam, 1995; De Grandpre and Bergeron, 1997; Brakenhielm and Liu, 1998; Bailey et al., 1998; Ruben et al., 1999), none have investigated the long-term effects of clearcutting and slash treatment in the Rocky Mountain region of North America. Our study focuses on 30-50-year-old post-harvest stands in the Medicine Bow Mountains of southeastern Wyoming. We compared post-harvest stands in different environments with different kinds of slash treatment, to adjacent, mature stands that originated after wildfire. 
Although long-term effects of clearcutting on forest understories have not been examined in Rocky Mountain coniferous forests, several studies have examined early successional trends. Dion (1998) compared understory species composition in 7-year-old stands treated with mechanical site preparation (roller-chopping and tractor walking) to that of untreated postharvest stands and mature uncut stands in the Sierra Madre Mountains to the west of our study area. She found that plant species richness was higher in clearcut than in adjacent mature stands due to invasion of wind-dispersed species (native and non-native), but that species richness did not differ between stands in which slash was treated and untreated. Cover of residual species (i.e., those present before harvesting) declined with disturbance intensity and there was a higher cover of non-native invaders in clearcut stands than in adjacent mature stands. However, exotic species comprised only $1-2 \%$ cover and did not differ in treated and untreated post-harvest stands. Dion (1998) also found less vegetation where soil disturbance was greater, although individual understory species responded differently to disturbance.

Similar results were obtained from studies examining effects of slash treatment on lodgepole pine regeneration patterns. Adams (1972) noted a seemingly direct correlation between presence of slash and presence of lodgepole pine seedlings, with piled and burned stands having lower rates of stocking than stands in which slash was compressed into the soil with several passes of a tractor or stands where slash was evenly distributed. Alexander (1964) suggested that higher stocking densities are achieved when slash is left untreated or is evenly distributed, compared to slash that is piled and burned.

Results from a long-term study in the western Cascade Range of Oregon after clearcutting in Douglas-fir forests appear to support the short-term pattern of understory species dynamics documented by Dion (1998) in the Rocky Mountain region (Halpern, 1988, 1989; Halpern and Franklin, 1990; Halpern and Spies, 1995). Most understory plant species survived disturbance and invading species colonized within 2 years after broadcast burning (Halpern, 1988). Succession was also affected by intensity of soil disturbance. Understories were dominated largely by residual species in relatively undisturbed sites (i.e., slash and forest floor left intact), and burned sites were domi- nated by invaders that colonized within two years after disturbance (Halpern, 1989). Although invaders of burned sites included non-native species, their importance declined with time.

Our study was motivated, in part, to determine if the short-term trends observed by Dion (1998) persist after 30-50 years of succession, and whether patterns in Rocky Mountain forests are similar to those in West Cascade Range forests (Halpern, 1988, 1989; Halpern and Franklin, 1990; Halpern and Spies, 1995). Our objectives were to examine the differences in species richness, species composition, and total cover of understory vegetation in 30-50-year-old post-harvest stands and adjacent mature post-fire stands, determine the influence of post-harvest slash treatments and elevation on the recovery of understory species, and assess the importance of non-native understory species in developing post-harvest stands. We hypothesized that: (1) elevation would have a significant effect on the recovery of forest understory species assemblages, with higher elevation forests recovering more slowly, (2) more intensive slash treatments (e.g., piling and burning) would negatively impact the long-term recovery of forest understories, and (3) cover of non-native understory species would be higher in 30-50-year-old post-harvest stands than in adjacent mature forest understories.

\section{Materials and methods}

\subsection{Study area}

Our study was conducted in the Snowy Range portion of the Medicine Bow National Forest (MBNF; $\left.41^{\circ} \mathrm{N}, 106^{\circ} \mathrm{W}\right)$, located in the Medicine Bow Mountains of southeastern Wyoming $(50 \mathrm{~km}$ west of Laramie). The Snowy Range encompasses approximately 218,600 ha and ranges in elevation from 2500 to $3700 \mathrm{~m}$ (Alexander et al., 1986). Precambrian gneiss and igneous rock underlie most of the Range (Houston, 1968), and soils in forested areas are usually Typic Cryochrepts and Typic Cryoboralfs (Knight, 1994). Mean annual precipitation ranges from $40 \mathrm{~cm}$ at lower elevations ( $\sim 2700 \mathrm{~m})$ to as much as $120 \mathrm{~cm}$ at higher elevations $(\sim 3200 \mathrm{~m})$, with roughly two-thirds of this falling as snow (Knight, 1994). Mean annual temperature is generally less than $2{ }^{\circ} \mathrm{C}$, with the potential for 
freezing temperatures during any month of the year (Martner, 1986).

Lodgepole pine (Pinus contorta Dougl. ex Loud. var. latifolia Engelm. ex Wats.) dominates forests at lower elevations (2500-3000 m) and on more xeric sites, comprising $66 \%$ of the forested land on the Snowy Range. Subalpine fir (Abies lasiocarpa (Hook.) Nutt.) and Engelmann spruce (Picea engelmannii Parry ex Engelm.) dominate forests at higher elevations (3000-3300 m) and on more mesic sites, covering $27 \%$ of the forested area (Alexander et al., 1986; Kipfmueller and Baker, 1998). All three species often occur together in mixed stands at middle elevations.

Common post-harvest slash-reduction treatments in the 1950s and 1960s included piling and burning, roller-chopping, lop and scatter, and, in selected areas, a combination of piling and burning and roller-chopping (L.T. Cartwright, personal communication; Walter Chesbro, personal communication; Boe, 1956; Alexander, 1964). The pile and burn technique employed a bulldozer with a brush rake rather than a blade to avoid incorporating too much soil into the slash piles. Burning took place within 2 years of harvest. Roller-chopping was common in the early 1960-1980s; a drum weighing approximately $9.2 \times$ $10^{3} \mathrm{~kg}$ was towed behind a bulldozer to compress slash into the soil. In the lop and scatter method, logging slash was cut into sections and distributed manually throughout the stand. Tree regeneration usually occurred naturally from seeds contained in logging slash or by seeds dispersed from adjacent uncut areas (Alexander, 1964; Dion, 1998). There is no record of artificial seeding or planting in any of the stands we studied.

We selected post-harvest stands that originated after clearcutting between 1950 and 1969 and that were adjacent to mature forests with similar environmental conditions (slope, aspect, elevation, soil-type). Mature stands were assumed to have initiated after fire, and we did not sample mature stands that had been thinned or had any evidence of selective harvest.

For each post-harvest stand, we determined harvest year, harvest technique, and thinning history using information contained within the Rocky Mountain Resource Information System (RM-RIS) database maintained by the MBNF. Information on the type and timing of slash treatments was not available for clearcuts originating in the 1950s and 1960s, so type of slash treatment was determined by on-site analysis of logging debris. Remnants of burned slash piles were still evident after 30-50 years (circular areas with low vegetation cover and abundant charcoal and charred coarse woody debris). Distinct chop-marks roughly $60 \mathrm{~cm}$ apart on larger woody debris indicated rollerchopping. Stands without evidence of burn-piles and chop-marks on logging debris were assumed to have been lopped and scattered. We assumed that slash treatments were implemented either immediately after harvesting or in the following year.

\subsection{Sampling}

We sampled 54 forest stands over two field seasons-30 post-harvest stands and 24 adjacent, mature uncut stands (Table 1). Sampling was done from midJune to late August in 1998 and 1999. Within each stand, we collected data along ten $50 \mathrm{~m}$ transect lines distributed at $\geq 10 \mathrm{~m}$ intervals and running perpendicular to a subjectively chosen baseline. At $10 \mathrm{~m}$ intervals along each transect, a $50 \mathrm{~cm} \times 100 \mathrm{~cm}$ point-frame with 36 points (Floyd and Anderson, 1982; Turner et al., 1997) was used to estimate cover and frequency of understory species and tree seedlings ( $<20 \mathrm{~cm}$ tall); a total of 50 frames (1800 points) was sampled in each stand. Importance values (IVs) were calculated as the sum of relative cover and relative frequency of each species (range of 0-200; Gilliam et al., 1995). Understory species were grouped into one of four categories for analysis of growth-form composition: tall shrubs, low shrubs, forbs, and graminoids. Non-native species were identified using a list compiled for Wyoming by Fertig (1999).

Tree species taller than $20 \mathrm{~cm}$ were sampled with $2 \mathrm{~m} \times 20 \mathrm{~m}$ plots running parallel to each $50 \mathrm{~m}$ transect. Tree species were classified into four categories: seedlings $(<20 \mathrm{~cm}$ tall; sampled with point-frame), short saplings $(\geq 20 \mathrm{~cm}$ but $<1.5 \mathrm{~m}$ tall), tall saplings $(\geq 1.5 \mathrm{~m}$ tall but $<4 \mathrm{~cm} \mathrm{dbh})$, and canopy trees ( $\geq 1.5 \mathrm{~m}$ tall, $\geq 4 \mathrm{~cm} \mathrm{dbh}$ ); only data for seedlings and canopy trees are presented here. For canopy trees, we recorded species, number, and diameter at breast height (dbh). Density (stems ha ${ }^{-1}$ ) and basal area $\left(\mathrm{m}^{2} \mathrm{ha}^{-1}\right)$ was calculated by species for canopy trees. Canopy height was estimated by measuring the height of 10 randomly selected canopy trees within each 
Table 1

Location, silvicultural treatments, and environmental characteristics of 30 sampled post-harvest stands ${ }^{\mathrm{a}}$

\begin{tabular}{|c|c|c|c|c|c|c|c|c|}
\hline $\begin{array}{l}\text { Post-harvest } \\
\text { stand }\end{array}$ & $\begin{array}{l}\text { USGS } 7.5^{\prime} \\
\text { quadrangle }\end{array}$ & $\begin{array}{l}\text { Year } \\
\text { harvested }\end{array}$ & Slash treatment & Thinned & $\begin{array}{l}\text { Elevation } \\
(\mathrm{m})\end{array}$ & Aspect & $\begin{array}{l}\text { Slope } \\
(\%)\end{array}$ & $\begin{array}{l}\text { Adjacent } \\
\text { mature }\end{array}$ \\
\hline FP1 & Foxpark & 1951 & Lop and scatter & $\mathrm{Y}$ & 2774 & SW & 5 & $\mathrm{~N}$ \\
\hline FP2 & Foxpark & 1951 & Lop and scatter & $\mathrm{Y}$ & 2804 & $\mathrm{E}$ & 5 & $\mathrm{Y}$ \\
\hline FP11 & Foxpark & 1960 & Both $\mathrm{PB}$ and $\mathrm{RC}$ & $\mathrm{N}$ & 2804 & $\mathrm{~N}$ & 8 & $\mathrm{Y}$ \\
\hline FP18 & Foxpark & 1969 & Roller-chop & $\mathrm{Y}$ & 2774 & $\mathrm{~N}$ & 24 & $\mathrm{Y}$ \\
\hline FP19 & Foxpark & 1969 & Both PB and RC & $\mathrm{Y}$ & 2773 & $\mathrm{~W}$ & 18 & $\mathrm{Y}$ \\
\hline FP20 & Foxpark & 1965 & Both PB and RC & $\mathrm{Y}$ & 2737 & $\mathrm{E}$ & 4 & $\mathrm{Y}$ \\
\hline WL2 & Woods Landing & 1957 & Lop and scatter & $\mathrm{Y}$ & 2710 & SW & 13 & $\mathrm{~N}$ \\
\hline WL18 & Woods Landing & 1957 & Lop and scatter & $\mathrm{Y}$ & 2743 & $\mathrm{NE}$ & 14 & $\mathrm{Y}$ \\
\hline WL19 & Woods Landing & 1957 & Lop and scatter & $\mathrm{Y}$ & 2731 & $\mathrm{~N}$ & 15 & $\mathrm{Y}$ \\
\hline $\mathrm{OH} 1$ & Overlook Hill & 1965 & Roller-chop & $\mathrm{Y}$ & 2805 & NW & 30 & $\mathrm{Y}$ \\
\hline HR25 & Horatio Rock & 1959 & Pile and burn & $\mathrm{Y}$ & 2792 & SE & 5 & $\mathrm{Y}$ \\
\hline HR36 & Horatio Rock & 1956 & Pile and burn & $\mathrm{Y}$ & 2750 & NE & 8 & $\mathrm{Y}$ \\
\hline HR37 & Horatio Rock & 1961 & Roller-chop & $\mathrm{N}$ & 2712 & $\mathrm{~S}$ & 25 & $\mathrm{Y}$ \\
\hline KS3 & Keystone & 1967 & Pile and burn & $\mathrm{N}$ & 2900 & SE & 5 & $\mathrm{Y}$ \\
\hline KS9 & Keystone & 1965 & Lop and scatter & $\mathrm{Y}$ & 2780 & $\mathrm{~S}$ & 15 & $\mathrm{~N}$ \\
\hline KS12 & Keystone & 1965 & Both PB and RC & $\mathrm{Y}$ & 2890 & $\mathrm{E}$ & 18 & $\mathrm{Y}$ \\
\hline KS13 & Keystone & 1965 & Both PB and RC & $\mathrm{N}$ & 2919 & $\mathrm{~S}$ & 12 & $\mathrm{Y}$ \\
\hline KS14 & Keystone & 1967 & Lop and scatter & $\mathrm{N}$ & 3010 & SE & 18 & $\mathrm{Y}$ \\
\hline TR122 & Turpin Reservoir & 1957 & Pile and burn & $\mathrm{Y}$ & 2865 & SW & 5 & $\mathrm{Y}$ \\
\hline SL27 & Sand Lake & 1957 & Pile and burn & $\mathrm{Y}$ & 3070 & SE & 10 & $\mathrm{Y}$ \\
\hline PL102 & Phantom Lake & 1963 & Pile and burn & $\mathrm{N}$ & 3010 & SE & 16 & $\mathrm{Y}$ \\
\hline PL102a & Phantom Lake & 1963 & Pile and burn & $\mathrm{N}$ & 3060 & SE & 16 & $\mathrm{Y}$ \\
\hline PL124 & Phantom Lake & 1965 & Roller-chop & $\mathrm{Y}$ & 2800 & NW & 10 & $\mathrm{Y}$ \\
\hline PL125 & Phantom Lake & 1966 & Lop and scatter & $\mathrm{Y}$ & 2877 & $\mathrm{~N}$ & 34 & $\mathrm{Y}$ \\
\hline PL126 & Phantom Lake & 1966 & Lop and scatter & $\mathrm{Y}$ & 2896 & NW & 24 & $\mathrm{Y}$ \\
\hline M7 & Morgan & 1969 & Roller-chop & $\mathrm{N}$ & 3050 & $\mathrm{NE}$ & 12 & $\mathrm{Y}$ \\
\hline M9 & Morgan & 1968 & Pile and burn & $\mathrm{N}$ & 3070 & NW & 10 & $\mathrm{Y}$ \\
\hline MB1 & Medicine Bow Peak & 1969 & Pile and burn & $\mathrm{N}$ & 3164 & NW & 12 & $\mathrm{Y}$ \\
\hline MB2 & Medicine Bow Peak & 1969 & Pile and burn & $\mathrm{N}$ & 3152 & NW & 18 & $\mathrm{Y}$ \\
\hline MB3 & Medicine Bow Peak & 1969 & Pile and burn & $\mathrm{N}$ & 3120 & $\mathrm{~N}$ & 14 & $\mathrm{Y}$ \\
\hline
\end{tabular}

a "N" under "adjacent mature" indicates no suitable mature forest stand within the vicinity of the post-harvest stand.

stand using a clinometer and taking the mean of those 10 measurements as the canopy height. Year of origin for post-harvest stands was available from USFS records. For the mature forests, we estimated stand age by counting annual growth rings on cores from five of the largest trees. Stand age was assumed to be the age of the oldest tree. We avoided coring trees that were much larger in diameter $(>15-20 \mathrm{~cm})$ or much older than the majority of trees in the stand, as these may have been survivors of the last fire.

Five soil samples were taken from the A horizon (approximately $5 \mathrm{~cm}$ below the top of the $\mathrm{O}$ horizon) in each stand and were combined. These composite samples were then analyzed for texture (percent sand, silt, and clay) using the hydrometer method (Miller and Kotuby-Amacher, 1998).

\subsection{Data analysis}

The stands we sampled occurred along a relatively broad elevation range (2710-3164 m; Table 1). We used two-way indicator species analysis (TWINSPAN; Hill, 1979) of mature stand understory IV data to objectively separate stands into two elevation zones: a high elevation, subalpine zone, in which subalpine fir and Engelmann spruce were the dominant canopy species, and a low- to mid-elevation montane zone, in which the forest canopy was dominated by lodgepole pine. We used two-sample $t$-tests to determine if there were statistically significant differences in elevation, soil-texture (percent sand), and stand age between montane and subalpine mature stands as classified by TWINSPAN ( $\alpha$ adjusted for the 
number of comparisons using the Bonferroni correction; Sokal and Rohlf, 1981).

Non-metric multidimensional scaling (NMS) was used to examine variation in understory composition in post-harvest and adjacent mature forest stands within and between the two elevation zones. NMS is an iterative best-fit technique that seeks to arrange samples (in this case forest stands) so that the distance between each pair of samples in ordination space is in rank order with their similarities in species composition (Clarke, 1993). Multiple iterations are performed to minimize lack of fit, or stress, between ordination distances and measures of dissimilarity based on species composition. We performed NMS on the IV data using the Sorensen (Bray-Curtis) metric as a measure of dissimilarity (Faith et al., 1987; McCune, 1997). Dimensionality was assessed by examining the change in stress as a function of dimension while stepping down from a six- to one-dimensional solution. We used an instability criterion of $1 \times 10^{-5}$ and performed 40 runs with real data and 50 runs with randomized data. The best solution for each dimensionality was selected as the real run with the lowest final stress on a scale of 0-100 (McCune and Mefford, 1999). Results indicated a two-dimensional solution was most parsimonious. Final stress for the two-dimensional solution was found to be lower than $95 \%$ of the randomized runs based on a Monte Carlo test. The ordination was rotated using the varimax method to maximize the elevation gradient along NMS axis 1, the most obvious gradient in the ordination.

We used multi-response permutation procedures (MRPP) to test the hypothesis of no difference in understory species composition between post-harvest stands and adjacent mature forest stands in both the montane and subalpine zones. MRPP is a non-parametric, multivariate method used to make statistical comparisons among two or more a priori groups (Zimmerman et al., 1985). The MRPP test statistic describes the separation between groups based on the weighted mean within-group distance, $A$ (McCune and Grace, 2002). The Sorensen distance metric was used to quantify the compositional distance, as it has been shown to be more robust than other distance measures (Faith et al., 1987; McCune and Mefford, 1999), and because it was used as the distance metric in the NMS ordination. The degree of similarity between post-harvest and mature forest understories, as measured by Sorensen distance, serves as an indicator of resilience, or the degree of community recovery (Halpern, 1988). The TWINSPAN classification, NMS ordination, and MRPP analyses were performed using the PC-ORD software package (PC-ORD v.4.2, 1999 MjM Software, Gleneden Beach, OR).

Differences in understory species richness, total vegetation cover, and cover by growth-form (tall shrubs, low shrubs, forbs, and graminoids) were examined with two-factor analysis of variance (ANOVA) for the main effects of harvesting (post-harvest vs. mature) and elevation zone (montane vs. subalpine), as well as their interaction. All percentage data (e.g., percent cover) were transformed using the arcsinesquare root transformation before statistical analysis to approximate normality (Sokal and Rohlf, 1981).

To determine if the type of slash treatment (lop and scatter, roller-chop, pile and burn, or the combination of roller-chopping and piling and burning) had an effect on the degree of similarity between post-harvest and mature forest understory species assemblages, we performed one-factor analysis of covariance (ANCOVA) with Sorensen distance as the response variable and elevation as the covariate. Sorensen distances between paired post-harvest and mature forest stands were calculated independent of one another. Least-squares means of the four slash treatment levels were compared using Tukey's HSD all pairwise comparisons. We used one-factor ANCOVA with elevation as the covariate rather than a two-factor ANOVA in order to maintain an adequate sample size among the four levels of slash treatment.

We summed the importance values of non-native species in each post-harvest stand and used a twosample $t$-test to determine if the importance of nonnative species differed between montane and subalpine post-harvest stands. We also determined if the importance of non-native species in post-harvest stands differed significantly among the four slash treatments using a one-way ANOVA. Statistical analyses were conducted using the SAS JMP IN v.4.0.4 software package (SAS Institute, 2001).

\section{Results}

Subalpine stands tended to have higher relative densities of Engelmann spruce and subalpine fir 
Table 2

Stand characteristics of post-harvest and mature stands in the montane and subalpine zones (data are means +1 S.E.)

\begin{tabular}{|c|c|c|c|c|}
\hline & \multicolumn{2}{|l|}{ Montane zone } & \multicolumn{2}{|c|}{ Subalpine zone } \\
\hline & Post-harvest & Mature & Post-harvest & Mature \\
\hline Total number of stems $\left(\mathrm{ha}^{-1}\right)$ & $1132(115)$ & $2003(301)$ & $1445(310)$ & $2451(255)$ \\
\hline \multicolumn{5}{|c|}{ Percentage of total number of stems (by species) } \\
\hline Lodgepole pine & $96(2)$ & $92(4)$ & $36(8)$ & $41(11)$ \\
\hline Subalpine fir & $4(2)$ & $7(4)$ & $53(9)$ & $42(8)$ \\
\hline Engelmann spruce & 0 & $1(0.3)$ & $11(3)$ & $17(5)$ \\
\hline Total basal area $\left(\mathrm{m}^{2} \mathrm{ha}^{-1}\right)$ & $14(1)$ & 3925 (199) & $8(1)$ & $6390(990)$ \\
\hline Mean dbh (cm) & $10(1)$ & $14(1)$ & $6(1)$ & $15(1)$ \\
\hline Stand age (years) & $41(2)$ & $180(22)$ & $37(2)$ & $231(15)$ \\
\hline
\end{tabular}

than montane stands, which were dominated by lodgepole pine (Table 2). Subalpine stands were significantly higher in elevation by an average of $227 \mathrm{~m}$ ( $t=6.8, P<0.001)$, and mature subalpine stands were significantly older than mature montane stands by an average of 70 years $(t=2.83, P=0.005)$. In addition to differences in elevation and mature stand age, subalpine stands had soils with significantly lower sand content $(t=6.48, P<0.0001)$.
Along the first axis of the two-dimensional NMS ordination, understory species composition of forest stands was separated according to elevation and percent soil sand content (Fig. 1 and Table 3), with montane stands representing the lower end of this axis (low elevation, high soil sand content) and subalpine stands representing the upper end (high elevation, low soil sand content). Mature montane stands had a higher proportion of Shepherdia canadensis,

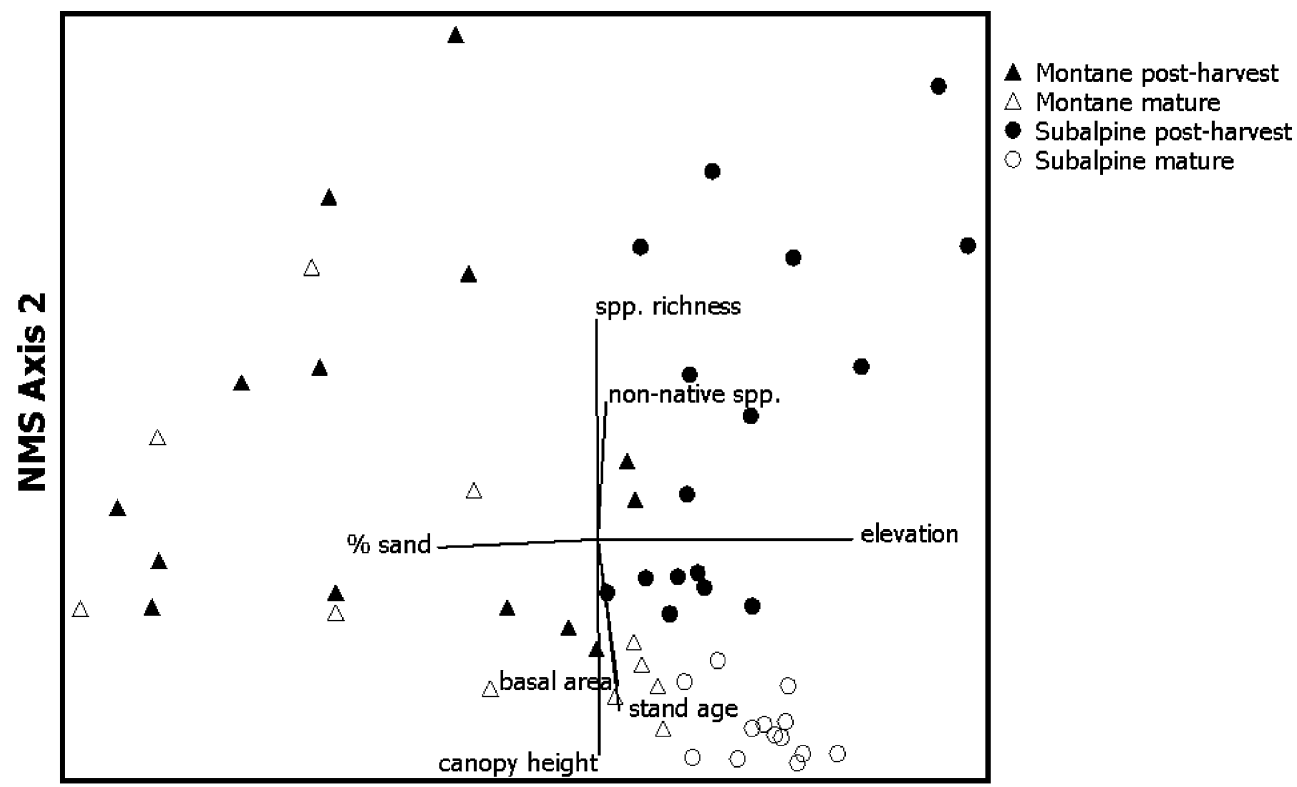

NMS Axis 1

Fig. 1. NMS ordination of understory species composition in post-harvest and adjacent mature forest stands. Vectors point in the direction of maximum change of the specified variable, and vector length indicates the degree of correlation between site variables and axes (see Table 3 for correlation coefficients). Ordination space was rotated to maximize the relationship between elevation and axis 1 . 
Table 3

Correlations between site variables and NMS ordination axis scores $^{\mathrm{a}}$

\begin{tabular}{lrr}
\hline Variable & Axis 1 & Axis 2 \\
\hline Elevation & 0.761 & -0.039 \\
Canopy height & 0.016 & -0.690 \\
Species richness & -0.018 & 0.698 \\
Stand age & 0.188 & -0.625 \\
Soil sand content & -0.609 & -0.101 \\
Tree basal area & 0.187 & -0.577 \\
Non-native spp. IVs & 0.154 & 0.546 \\
Tree canopy cover & -0.295 & 0.118 \\
Slope & 0.046 & -0.135 \\
Tree density & 0.128 & -0.130 \\
\hline
\end{tabular}

${ }^{\mathrm{a}}$ Correlation coefficients $(r)$ were calculated after ordination space was rotated to maximize the relationship between elevation and axis 1.

Juniperus communis, Arnica cordifolia, and Carex geyeri than mature subalpine forest understories which were dominated by Vaccinium scoparium (Table 4). Forest stands separated along the second NMS axis according to factors related to timber harvesting (Fig. 1). NMS axis 2 was negatively correlated with canopy height, stand age, and stand basal area, and positively correlated with plant species richness and summed importance values of non-native species (Table 3). Mature stands represented the lower end of this axis while post-harvest stands represented the upper end (Fig. 1). Species present in montane post-harvest stands but absent or rare from adjacent mature stands included Achillea millefolium, Anaphalis margaritacea, Taraxacum officinale, Ceanothus velutinus, Purshia tridentata, and Trisetum spicatum (Table 4). Species present in subalpine post-harvest stands more often than in adjacent mature stands included Phleum alpinum, Lonicera involucrata, T. spicatum, Juncus drummondii, Luzula parvifolia, and several Carex species (Table 4).

The NMS ordination also revealed an apparently greater separation between post-harvest and mature stands in the subalpine zone than the montane zone (Fig. 1). MRPP analysis confirmed this pattern: in the subalpine zone there was a significant difference in species composition between post-harvest and mature stands $(A=0.195, P<0.001)$. However, there was no significant difference in species composition between post-harvest and mature stands in the montane zone ( $A=0.025, P=0.064)$.

There was a significant interaction effect of harvesting and elevation zone on plant species richness per stand (Table 5), such that timber harvesting at higher elevations resulted in a greater long-term increase in species richness than timber harvesting in the montane zone (Fig. 2). Total cover of understory species did not differ between post-harvest and mature forest stands (Table 5). However, there was a significant effect of elevation zone (Table 5), with mean total vegetation



Fig. 2. Species richness in post-harvest and adjacent mature montane and subalpine forest understories. Data are means +1 S.E. 
Table 4

Mean percent cover of understory species in post-harvest and mature montane and subalpine forest stands ${ }^{\mathrm{a}}$

\begin{tabular}{|c|c|c|c|c|}
\hline \multirow[t]{2}{*}{ Species } & \multicolumn{2}{|l|}{ Montane } & \multicolumn{2}{|l|}{ Subalpine } \\
\hline & Post-harvest & Mature & Post-harvest & Mature \\
\hline \multicolumn{5}{|l|}{ Low shrubs } \\
\hline Arctostaphylos uva-ursi & 0.07 & 0.09 & 0.00 & 0.00 \\
\hline Chimaphala umbellata & 0.00 & 0.01 & 0.00 & 0.01 \\
\hline Mahonia repens & 0.38 & 0.32 & 0.28 & 0.04 \\
\hline Pyrola chlorantha & 0.08 & 0.05 & 0.03 & 0.06 \\
\hline Ribes inerme & 0.00 & 0.00 & 0.02 & 0.00 \\
\hline R. woodsii & 0.67 & 0.24 & 0.24 & 0.01 \\
\hline Rubus idaeus & 0.00 & 0.00 & 0.11 & 0.00 \\
\hline Vaccinium caespitosum & 0.21 & 0.37 & 0.00 & 0.00 \\
\hline V. scoparium & 8.22 & 13.94 & 27.93 & 52.17 \\
\hline \multicolumn{5}{|l|}{ Tall shrubs and tree seedlings } \\
\hline A. lasiocarpa & 0.03 & 0.15 & 0.21 & 0.12 \\
\hline C. velutinus & 0.21 & 0.00 & 0.00 & 0.00 \\
\hline J. communis & 3.77 & 1.37 & 0.68 & 0.04 \\
\hline L. involucrata & 0.00 & 0.00 & 0.09 & 0.00 \\
\hline P. engelmannii & 0.00 & 0.00 & 0.03 & 0.09 \\
\hline P. contorta & 0.09 & 0.10 & 0.05 & 0.01 \\
\hline P. tridentata & 0.12 & 0.00 & 0.00 & 0.00 \\
\hline Salix scouleriana & 0.00 & 0.00 & 0.03 & 0.00 \\
\hline S. canadensis & 1.60 & 1.84 & 0.10 & 0.00 \\
\hline \multicolumn{5}{|l|}{ Forbs } \\
\hline A. millefolium & 0.21 & 0.00 & 0.56 & 0.00 \\
\hline Agoseris aurantiaca & 0.01 & 0.00 & 0.09 & 0.00 \\
\hline Agoseris glaиса & 0.01 & 0.00 & 0.16 & 0.00 \\
\hline A. margaritacea & 0.03 & 0.00 & 0.37 & 0.00 \\
\hline Antennaria rosea & 0.51 & 0.09 & 0.86 & 0.00 \\
\hline Arabis drummondii & 0.02 & 0.01 & 0.04 & 0.00 \\
\hline Arenaria congesta & 0.07 & 0.10 & 0.00 & 0.00 \\
\hline A. cordifolia & 1.66 & 1.23 & 1.53 & 0.34 \\
\hline Arnica mollis & 0.00 & 0.05 & 0.15 & 0.00 \\
\hline Arnica parryi & 0.00 & 0.00 & 0.57 & 0.00 \\
\hline Caltha leptosepala & 0.00 & 0.00 & 0.01 & 0.00 \\
\hline Castilleja rhexifolia & 0.00 & 0.00 & 0.02 & 0.00 \\
\hline Cirsium centaureae & 0.01 & 0.00 & 0.00 & 0.00 \\
\hline Draba sp. & 0.00 & 0.00 & 0.04 & 0.00 \\
\hline Epilobium angustifolium & 0.88 & 0.05 & 1.25 & 0.08 \\
\hline Epilobium halleanum & 0.00 & 0.00 & 0.04 & 0.00 \\
\hline Erigeron peregrinus & 0.00 & 0.13 & 1.46 & 0.44 \\
\hline Erythronium grandiflorum & 0.00 & 0.00 & 0.04 & 0.00 \\
\hline Fragaria virginiana & 0.68 & 0.15 & 0.35 & 0.07 \\
\hline Gentianella amarella & 0.00 & 0.00 & 0.03 & 0.00 \\
\hline Geranium richardsonii & 0.00 & 0.00 & 0.03 & 0.00 \\
\hline Hieracium albiflorum & 0.28 & 0.18 & 0.26 & 0.03 \\
\hline Hieracium gracile & 0.19 & 0.02 & 1.57 & 0.02 \\
\hline Ligusticum porteri & 0.00 & 0.00 & 0.20 & 0.02 \\
\hline L. vulgaris & 0.00 & 0.00 & 0.04 & 0.00 \\
\hline Lupinus argenteus & 1.17 & 0.10 & 2.89 & 0.01 \\
\hline Orthilia secunda & 0.00 & 0.00 & 0.00 & 0.03 \\
\hline
\end{tabular}


Table 4 (Continued)

\begin{tabular}{|c|c|c|c|c|}
\hline \multirow[t]{2}{*}{ Species } & \multicolumn{2}{|l|}{ Montane } & \multicolumn{2}{|l|}{ Subalpine } \\
\hline & Post-harvest & Mature & Post-harvest & Mature \\
\hline Osmorhiza depauperata & 0.00 & 0.01 & 0.02 & 0.05 \\
\hline Pedicularis racemosa & 0.00 & 0.00 & 0.00 & 0.13 \\
\hline Penstemon saxosorum & 0.00 & 0.00 & 0.01 & 0.00 \\
\hline Penstemon whippleanus & 0.00 & 0.00 & 0.39 & 0.00 \\
\hline Plantago tweedyi & 0.00 & 0.00 & 0.04 & 0.00 \\
\hline Potentilla fissa & 0.05 & 0.01 & 0.00 & 0.00 \\
\hline Senecio crassulus & 0.00 & 0.00 & 1.44 & 0.00 \\
\hline Senecio cronatus & 0.04 & 0.00 & 0.19 & 0.00 \\
\hline Senecio eremophilus & 0.00 & 0.06 & 0.02 & 0.05 \\
\hline Sibbaldia procumbens & 0.00 & 0.00 & 0.86 & 0.00 \\
\hline Silene menziessii & 0.00 & 0.00 & 0.01 & 0.00 \\
\hline Solidago multiradiata & 0.09 & 0.02 & 0.87 & 0.00 \\
\hline Solidago parryi & 0.05 & 0.04 & 0.08 & 0.00 \\
\hline Taraxacum sp. & 0.49 & 0.00 & 1.09 & 0.00 \\
\hline Veronica wormskjoldii & 0.00 & 0.00 & 0.08 & 0.00 \\
\hline \multicolumn{5}{|l|}{ Graminoids } \\
\hline \multicolumn{5}{|l|}{ Grasses } \\
\hline Alepocuris pratensis & 0.00 & 0.00 & 0.09 & 0.00 \\
\hline Bromus carinatus & 0.00 & 0.00 & 0.08 & 0.00 \\
\hline Calamagrostis canadensis & 0.00 & 0.00 & 0.02 & 0.01 \\
\hline Calamagrostis inexpansa & 0.00 & 0.01 & 0.00 & 0.00 \\
\hline Calamagrostis rubescens & 0.00 & 0.00 & 0.39 & 0.00 \\
\hline Danthonia intermedia & 0.01 & 0.00 & 0.03 & 0.01 \\
\hline Deschampsia cespitosa & 0.00 & 0.00 & 0.55 & 0.03 \\
\hline Elymus glaucodes & 0.06 & 0.01 & 0.00 & 0.00 \\
\hline Oryzopsis exigua & 0.41 & 0.06 & 0.00 & 0.00 \\
\hline P. alpinum & 0.00 & 0.00 & 0.90 & 0.00 \\
\hline Poa fendleriana & 0.02 & 0.01 & 0.01 & 0.00 \\
\hline Poa nervosa & 0.26 & 0.14 & 0.22 & 0.00 \\
\hline Poa pratensis & 0.00 & 0.00 & 0.58 & 0.00 \\
\hline Poa sp. & 0.00 & 0.00 & 0.07 & 0.00 \\
\hline Trisetum wolfii & 0.00 & 0.00 & 0.04 & 0.00 \\
\hline Tristetum spicatum & 0.08 & 0.01 & 1.25 & 0.00 \\
\hline \multicolumn{5}{|l|}{ Sedges } \\
\hline C. geyeri & 0.83 & 1.27 & 0.37 & 0.04 \\
\hline Carex haydeniana & 0.00 & 0.02 & 1.18 & 0.00 \\
\hline Carex hoodii & 0.00 & 0.00 & 0.02 & 0.00 \\
\hline Carex microptera & 0.00 & 0.00 & 0.15 & 0.00 \\
\hline Carex occidentalis & 0.00 & 0.00 & 0.31 & 0.00 \\
\hline Carex phaeocephala & 0.00 & 0.00 & 0.03 & 0.00 \\
\hline Carex raynoldsii & 0.00 & 0.00 & 0.13 & 0.00 \\
\hline Carex rossii & 1.07 & 0.55 & 1.61 & 0.62 \\
\hline \multicolumn{5}{|l|}{ Rushes } \\
\hline J. drummondii & 0.00 & 0.03 & 1.62 & 0.00 \\
\hline L. parvifolia & 0.00 & 0.00 & 0.04 & 0.00 \\
\hline
\end{tabular}

\footnotetext{
${ }^{\text {a }}$ Fifty quadrats $(50 \mathrm{~cm} \times 100 \mathrm{~cm})$ were sampled in each stand.
} 


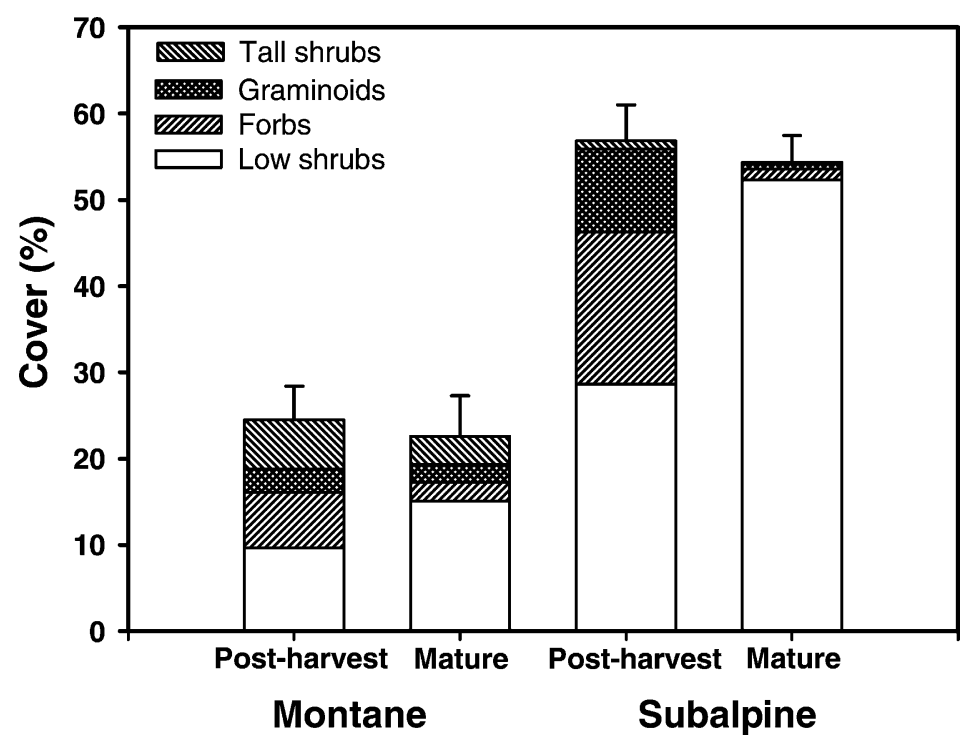

Fig. 3. Mean percent cover of understory vegetation by growth-form in post-harvest and adjacent mature montane and subalpine forest stands. Error bars represent 1 S.E.

cover of subalpine stands approximately twice that of montane stands (Fig. 3).

Although total understory vegetation cover was similar in post-harvest and adjacent mature forest stands, both harvesting and elevation zone had significant effects on the cover of different growth-forms (Table 5). There was a significant harvest by elevation zone interaction effect on the cover of both forbs and graminoids (Table 5), such that there was a disproportionately greater long-term increase in forb and graminoid cover from harvesting subalpine stands than from harvesting montane stands (Fig. 3). The effects of harvesting and elevation on the cover of low shrubs (primarily V. scoparium; Table 4) and tall



Fig. 4. Sorensen distance between post-harvest and adjacent mature forest understory species assemblages following different post-harvest slash treatments. Data are least-squares means adjusted for elevation +1 S.E. Means with the same letter do not differ significantly based a one-factor ANCOVA and Tukey-Kramer HSD all pairwise comparisons test. 
Table 5

ANOVA for species richness, total cover of understory species, and cover by growth-form

\begin{tabular}{|c|c|c|c|c|}
\hline Source & d.f. & MS & $F$ & $P>F$ \\
\hline \multicolumn{5}{|l|}{ Species richness } \\
\hline Harvest & 1 & 1967.84 & 34.59 & $<0.0001$ \\
\hline Elevation zone & 1 & 2.25 & 0.04 & 0.8430 \\
\hline Harvest $\times$ elevation zone & 1 & 260.67 & 4.58 & 0.0373 \\
\hline Error & 48 & 56.89 & & \\
\hline \multicolumn{5}{|l|}{ Total cover } \\
\hline Harvest & 1 & 0.0081 & 0.28 & 0.6010 \\
\hline Elevation zone & 1 & 1.6087 & 55.14 & $<0.0001$ \\
\hline Harvest $\times$ elevation zone & 1 & 0.0001 & 0.01 & 0.9456 \\
\hline Error & 48 & 0.0292 & & \\
\hline \multicolumn{5}{|l|}{ Forbs } \\
\hline Harvest & 1 & 0.5952 & 41.14 & $<0.0001$ \\
\hline Elevation zone & 1 & 0.0748 & 5.17 & 0.0273 \\
\hline Harvest $\times$ elevation zone & 1 & 0.1743 & 12.05 & 0.0011 \\
\hline Error & 48 & 0.0145 & & \\
\hline \multicolumn{5}{|l|}{ Graminoids } \\
\hline Harvest & 1 & 0.2065 & 14.49 & 0.0004 \\
\hline Elevation zone & 1 & 0.0195 & 1.37 & 0.2477 \\
\hline Harvest $\times$ elevation zone & 1 & 0.1254 & 8.80 & 0.0046 \\
\hline Error & 48 & 0.0143 & & \\
\hline \multicolumn{5}{|l|}{ Low shrubs } \\
\hline Harvest & 1 & 0.4674 & 12.08 & 0.0010 \\
\hline Elevation zone & 1 & 1.6762 & 43.33 & $<0.0001$ \\
\hline Harvest $\times$ elevation zone & 1 & 0.1119 & 2.89 & 0.0951 \\
\hline Error & 48 & 0.0387 & & \\
\hline \multicolumn{5}{|l|}{ Tall shrubs } \\
\hline Harvest & 1 & 0.03224 & 3.77 & 0.0477 \\
\hline Elevation zone & 1 & 0.2670 & 31.23 & $<0.0001$ \\
\hline Harvest $\times$ elevation zone & 1 & 0.0035 & 0.41 & 0.5242 \\
\hline Error & 48 & 0.0086 & & \\
\hline
\end{tabular}

shrubs were additive (Table 5). Low shrub cover was significantly higher in post-harvest stands than in adjacent mature stands, and low shrub cover in subalpine stands was two to fivefold higher than in montane stands (Table 5 and Fig. 3). Tall shrub cover was significantly higher in post-harvest stands than in mature stands, and significantly lower in subalpine stands than in montane stands (Table 5 and Fig. 3). Tall shrub cover in mature subalpine stands was essentially zero (Fig. 3).

When adjusted for elevational differences, compositional dissimilarity between post-harvest and adjacent, mature forests was greater when slash was piled and burned than when it was roller-chopped or lopped and scattered (Fig. 4). However, there were no significant differences in dissimilarity among stands where slash was lopped and scattered, roller-chopped, or roller-chopped and piled and burned (Fig. 4).

At least one non-native species was present in 26 of the 30 post-harvest stands (87\%), but their overall importance was low, with cover values generally less than $1 \%$. Only seven non-native species were encountered in post-harvest stands: Cirsium arvense, Linaria vulgaris, Poa compressa, P. palustris, P. pratensis, Taraxacum laevigatum, and T. officinale. Two of these, C. arvense and L. vulgaris, are considered noxious weeds in Wyoming (Fertig, 1999). Non-native species were essentially absent from mature forests, with only one species, $T$. officinale, found in a single stand with cover and frequency of $<1 \%$. Summed non-native IVs were not significantly different, on average, between montane and subalpine post-harvest stands $(t=0.19, P=0.76)$, and there was no significant difference in the importance of non-native species among the different types of slash treatment $(F=1.44$, $P=0.253)$.

\section{Discussion}

By comparing 30-50-year-old post-harvest forests to adjacent mature forests across a broad range of environmental conditions, we were able to determine some of the long-term impacts of timber harvesting on forest understory species composition in the Medicine Bow Mountains of southeastern Wyoming. Our primary finding was that montane post-harvest understories were more similar to adjacent mature forests 30-50 years after clearcutting than were comparable subalpine forest understories, suggesting that montane forests recover more rapidly after harvesting. Type of slash treatment also had a long-term effect on forest understory recovery, with the greatest negative impact from piling and burning. Non-native species were encountered more often in clearcut stands than in adjacent mature forests, where they were largely absent. Although present in nearly all the post-harvest stands we studied, non-native plant species were not a significant component of post-harvest understories after 30-50 years of succession.

Montane forest understories appear to recover more rapidly after harvesting than do subalpine forest 
understories. The substantial differences in community composition, vegetation density, and physical environment between montane and subalpine forests may have led to differences in resiliency. Climatic effects associated with elevation undoubtedly make some contribution to compositional differences, as higher elevation subalpine forests dominated by Engelmann spruce and subalpine fir are generally cooler and wetter than lower elevation montane forests dominated by lodgepole pine (Martner, 1986; Smith and Knapp, 1990; Knight, 1994). Compositional differences may also reflect differences in fire regime between montane and subalpine forests. Fire return intervals are considerably shorter in montane lodgepole pine than in subalpine spruce-fir forests (Romme and Knight, 1981; Peet, 2000), and thus understory species that can persist in montane forests are most likely better adapted to disturbance. Mature subalpine forest stands tended to be older than mature montane stands (Table 2), further suggesting a shorter fire rotation in lower elevation lodgepole pine forests. Alternatively, post-harvest and mature stands in the montane zone may be more similar simply because they differ less in age than do the comparable subalpine forests (Table 2).

In addition to the influences of climate and fire regime, the resilience of montane vs. subalpine understories may also be affected by the diversity of species present at the time of disturbance. Tilman and Downing (1994) suggested that communities with high species richness are more resilient because they are more likely to contain disturbance-resistant species. Montane mature forest understories tended to be dominated by a combination of species representing a variety of growth-forms (Table 4 and Fig. 3), while one species, V. scoparium, comprised $>90 \%$ of the understory plant cover in subalpine mature stands. Many of the dominant species in montane forests (e.g., Sheperdia canadensis, J. communis, A. cordifolia, $C$. geyeri, and Rosa woodsii) show increased regeneration in response to disturbance, either through sprouting, layering, or seedling establishment (Blauer et al., 1975; Mauk and Henderson, 1984; Noble, 1985; Noste and Bushey, 1988; Diotte and Bergeron, 1989; Steele and Geier-Hayes, 1987; Hansen et al., 1990; Stickney, 1990). In contrast, cover of $V$. scoparium often declines in response to disturbance (Zager, 1980; Zager et al., 1983; Lyon, 1984; Dion, 1998).
Seedling establishment is uncommon (Hungerford, 1986; Crossley, 1974), and although it can reproduce vegetatively (Hitchcock et al., 1959; McClean, 1968; Forcella and Weaver, 1977; Steele and Geier-Hayes, 1987), the rhizomes of $V$. scoparium may be easily damaged because of their shallow location between the forest floor and mineral soil (McClean, 1968; Richardson, 1980; Zager, 1980; Zager et al., 1983; Lyon, 1984; Dion, 1998). Survivors of disturbance events are often restricted to protected microsites, such as under fallen logs (Richardson, 1980). We observed that clumps of $V$. scoparium in post-harvest stands were often concentrated under and around logs that appeared to have been less disturbed than adjacent areas.

Slash disposal techniques differed significantly in their long-term impact on understory recovery after timber harvesting, regardless of stand elevation. Piling and burning had the greatest detrimental effect, while roller-chopping and lopping and scattering had less impact on understory species recovery (Fig. 4). In a study of slash disposal techniques in central Montana, Boe (1956) noted that roughly half the soil surface area in block clearcuts was severely disturbed when slash was piled and burned, but there was virtually no surface soil disturbance when slash was lopped and scattered. Roller-chopping has also been found to cause less soil disturbance compared to the soil scarification and intense soil heating associated with piling and burning (Stein, 1995; Kovalchik and Blake, 1972). Our results suggest that more intensive slash disposal techniques such as piling and burning can negatively impact understory species composition for decades after clearcutting, especially in stands dominated by species sensitive to disturbance such as V. scoparium.

Reduction of $V$. scoparium due to harvesting and slash treatment in subalpine stands, combined with its apparent inability to rapidly re-colonize disturbed sites from adjacent mature stands, would likely leave large areas of open habitat available for establishment of shade-intolerant species, especially if mineral soil was exposed (McIntyre et al., 1995). As a consequence, succession in subalpine post-harvest stands appears to have been driven primarily by colonization from off-site by non-forest, wind-dispersed graminoids, forbs, and tall shrubs. Tree establishment on high-elevation disturbed sites may be slow due to the 
harsh environment, or due to intense competition from graminoid and forb species that establish rapidly after disturbance (Stahelin, 1943; Noble and Ronco, 1978). This delay in canopy closure allows shade-intolerant plant species that are atypical of mature subalpine forests to persist for decades.

Alternatively, succession in montane post-harvest forests appears to have been driven either by residual plants and seeds present at the time of disturbance or by propagule dispersal of forest understory species from adjacent undisturbed stands. Since we have no information on species composition immediately following harvesting and slash treatment, the relative importance of residual plants and seeds vs. off-site invaders is unknown. However, studies of early successional post-fire and post-harvest lodgepole pine forests in Wyoming have shown that, even on moderately to severely disturbed sites, plant cover is dominated by re-sprouting survivors (Turner et al., 1997; Dion, 1998; Doyle et al., 1998). In addition to being well adapted to survive disturbance, several montane species such as A. cordifolia, C. geyeri, and $R$. woodsii are tolerant of full sun to at least moderate shade, and thus are found in both early and late seral communities (Blauer et al., 1975; Mauk and Henderson, 1984; Steele and Geier-Hayes, 1987; Hansen et al., 1990; Stickney, 1990). The broad tolerance range and disturbance adaptations of many montane understory species may partially explain why montane post-harvest understory composition is not significantly different from that of adjacent mature forests after 30-50 years of succession.

Low-elevation forests dominated by lodgepole pine on the MBNF are more resilient than high-elevation spruce-fir forests. Halpern $(1988,1989)$ suggested a deterministic component to secondary succession based on the life history traits of individual species. Our study supports this suggestion, in that subalpine stands dominated by $V$. scoparium, with its shallow rhizomes and poor seedling establishment, recover more slowly from disturbance, especially where soil disturbance caused by slash treatment is high. A combination of factors may facilitate the more rapid recovery of montane forests understories, including a longer growing season at lower elevations, higher species richness, and a greater proportion of species with the potential to regenerate or re-colonize after disturbance.

\section{Acknowledgements}

Our research was supported through a contract with the Medicine Bow-Routt National Forest. We thank Jerry Schmidt, Dee Hines, Mike Sanders, Carol Tolbert, Tom Cartwright, and Walter Chesbro of the Medicine Bow National Forest for assistance with logistics, site locations, and logging history information. We also thank Donna Ehle and Melissa Bartley for assistance with field and laboratory work; Ron Hartman, Burrell E. Nelson, and Walter Fertig of the Rocky Mountain Herbarium and Wyoming Natural Diversity Database for assistance with plant identification; and Stephen T. Jackson and William L. Baker as well as two anonymous reviewers, for helpful comments on earlier versions of this manuscript.

\section{References}

Adams, D.L., 1972. Natural regeneration following four treatments of slash on clearcut areas of lodgepole pine-a case history. Station Note No. 19. Forestry, Wildlife and Range Experiment Station, University of Idaho, Moscow, ID.

Alexander, R.R., 1964. Establishment of lodgepole pine reproduction after different slash disposal treatments. USDA Forest Service Research Note No. RM-62.

Alexander, R.R., Hoffman, G.R., Wirsing, J.M., 1986. Forest vegetation of the Medicine Bow National Forest in southeastern Wyoming: a habitat type classification. USDA Forest Service Research Paper No. RM-271.

Bailey, J.D., Mayrsohn, C., Doescher, P.S., St. Pierre, E., Tappeiner, J.C., 1998. Understory vegetation in old and young Douglas-fir forests of western Oregon. For. Ecol. Manage. 112, 289302.

Blauer, A.C., Plummer, A.P., McArthur, E.D., 1975. Characteristics and hybridization of important Intermountain shrubs. I. Rose family. USDA Forest Service Research Paper No. INT-169.

Boe, K.N., 1956. Regeneration and slash disposal in lodgepole pine clear cuttings. Northw. Sci. 30, 1-11.

Bormann, F.H., Likens, G.E., 1979. Pattern and Process in a Forested Ecosystem. Springer, New York, NY.

Brakenhielm, S., Liu, Q., 1998. Long-term effects of clear-felling on vegetation dynamics and species diversity in a boreal pine forest. Biodiversity Conserv. 7, 207-220.

Clarke, K.R., 1993. Non-parametric multivariate analyses of changes in community structure. Aust. J. Ecol. 18, 117-143.

Corns, I.G.W., LaRoi, G.H., 1976. A comparison of mature with recently clear-cut and scarified lodgepole pine forests in the Lower Foothills of Alberta. Can. J. For. Res. 6, 20-32.

Crossley, J.A., 1974. Vaccinium L. Blueberry. In: Schopmeyer, C.S. (Ed.), Seeds of Woody Plants in the United States. USDA Forest Service Agricultural Handbook No. 450, pp. 840-843. 
De Grandpre, L., Bergeron, Y., 1997. Diversity and stability of understorey communities following disturbance in the southern boreal forest. J. Ecol. 85, 777-784.

De Grandpre, L., Gagnon, D., Bergeron, Y., 1993. Changes in the understory of Canadian southern boreal forest after fire. J. Veg. Sci. 4, 803-810.

Dion, A.N., 1998. Vegetation response to slash treatment and soil disturbance after clearcutting in a Rocky Mountain conifer forest. Master's Thesis. Department of Geography and Recreation, University of Wyoming, Laramie, WY.

Diotte, M., Bergeron, Y., 1989. Fire and the distribution of Juniperus communis $\mathrm{L}$. in the boreal forest of Quebec, Canada. J. Biogeogr. 16 (1), 91-96.

Doyle, K.M., Knight, D.H., Taylor, D.L., Barmore, W.J., Benedict, J.M., 1998. Seventeen years of forest succession following the Waterfalls Canyon fire in Grand Teton National Park, Wyoming. International Journal of Wildland Fire 8 (1), $45-55$.

Faith, D.P., Minchin, P.R., Belbin, L., 1987. Compositional dissimilarity as a robust measure of ecological distance. Vegetatio 69, 57-68.

Fertig, W., 1999. Non-native plants of Wyoming. Castilleja 18 (2), $7-10$.

Forcella, F., Weaver, T., 1977. Biomass an productivity of the subalpine Pinus albicaulis-Vaccinium scoparium association in Montana, USA. Vegetatio 35 (2), 95-105.

Floyd, D.A., Anderson, J.E., 1982. A new point interception frame for estimating cover of vegetation. Vegetatio 50, 185-186.

Gilliam, F.S., Turrill, N.L., Adams, M.B., 1995. Herbaceous and overstory species in clear-cut and mature Central Appalachian hardwood forests. Ecol. Appl. 5 (4), 947-955.

Grumbine, R.E., 1994. What is ecosystem management. Conserv. Biol. 8 (1), 27-38.

Halpern, C.B., 1988. Early successional pathways and the resistance and resilience of forest communities. Ecology 69 (6), 1703-1715.

Halpern, C.B., 1989. Early successional patterns of forest species: interactions of life-history traits and disturbance. Ecology 70 (3), 704-720.

Halpern, C.B., Franklin, J.F., 1990. Physiognomic development of Pseudotsuga forests in relation to initial structure and disturbance intensity. J. Veg. Sci. 1, 475-482.

Halpern, C.B., Spies, T.A., 1995. Plant diversity in natural and managed forests of the Pacific Northwest. Ecol. Appl. 5 (4), 913-934.

Hansen, P., Boggs, K., Pfister, R., Joy, J., 1990. Classification and management of riparian and wetland sites in central and eastern Montana. Montana Forest and Conservation Experiment Station, Missoula, MT, 279 pp.

Hill, M.O., 1979. TWINSPAN-A FORTRAN program for arranging multivariate data in an ordered two-way table by classification of the individuals and attributes. Ecology and Systematics, Cornell University, Ithaca, NY.

Hitchcock, C.L., Cronquist, A., Ownbey, M., 1959. Vascular plants of the Pacific Northwest. Part 4. Ericaceae through Campanulaceae. University of Washington Press, Seattle, WA, 510 pp.
Houston, R.S., 1968. A regional study of rocks of Precambrian age in that part of the Medicine Bow Mountains lying in southeastern Wyoming: with a chapter on the relationship between Precambrian and Laramide structure. Memoir, Geological Survey of Wyoming, $167 \mathrm{pp}$.

Hungerford, R.D., 1986. Vegetation response to stand cultural operations on small stem lodgepole pine stands in Montana. In: Weed Control for Forest Productivity in the Interior West, Spokane, WA, February 5-7, 1985. Washington State University Cooperative Extension Service, Pullman, WA, pp. 63-71.

Kipfmueller, K.F., Baker, W.L., 1998. Fires and dwarf mistletoe in a Rocky Mountain lodgepole pine ecosystem. For. Ecol. Manage. 108, 77-84.

Knight, D.H., 1994. Mountains and Plains: The Ecology of Wyoming Landscapes. Yale University Press, New Haven, CT, 338 pp.

Kovalchik, B., Blake, G., 1972. The effect of piling and burning versus chopping of logging residues on natural regeneration of serotinous lodgepole pine forests. Research Note No. 11. Montana Forest and Conservation Experiment Station, School of Forestry, University of Montana, Missoula, MT.

Lyon, L.J., 1984. The sleeping child burn-21 years of post-fire succession following large northern Rocky Mountain wildfires. USDA Forest Service Research Paper No. INT-330.

Martner, B.E., 1986. Wyoming Climate Atlas. University of Nebraska Press, Lincoln, 432 pp.

Mauk, R.L., Henderson, J.A., 1984. Coniferous forest habitat types of northern Utah. USDA Forest Service General Technical Report No. INT-170.

McClean, A., 1968. Fire resistance of forest species as influenced by root systems. J. Range Manage. 22, 120-122.

McCune, B., 1997. Influence of noisy environmental data on canonical correspondence analysis. Ecology 78, 2617-2623.

McCune, B., Grace, J.B., 2002. Analysis of Ecological Communities. MjM Software Design, Gleneden Beach, OR.

McCune, B., Mefford, M.J., 1999. PC-ORD: Multivariate Analysis of Ecological Data, Version 4. MjM Software Design, Gleneden Beach, OR.

McIntyre, S., Lavorel, S., Tremont, R.M., 1995. Plant life-history attributes: their relation to disturbance response in herbaceous vegetation. J. Ecol. 83, 31-44.

Miller, R.O., Kotuby-Amacher, J., 1998. Western States Laboratory Proficiency Testing Program: Soil and Plant Analytical Methods. Western States Program, Version 4.10.

Noble, W., 1985. Shepherdia canadensis: its ecology, distribution, and utilization by the grizzly bear. Unpublished Paper. USDA Forest Service, Fire Sciences Laboratory, Missoula, MT, 28 pp.

Noble, D.L., Ronco, F., 1978. Seedfall and establishment of Engelmann spruce and subalpine fir in clearcut openings in Colorado. USDA Forest Service Research Paper No. RM-200.

Noste, N.V., Bushey, C.L., 1988. Aspen community types of the Intermountain Region. USDA Forest Service General Technical Report No. INT-239.

Peet, R.K., 2000. Forests and meadows of the Rocky Mountains. In: Barbour, M.G., Billings, W.D. (Eds.), North American Terrestrial Vegetation. Cambridge University Press, Cambridge, UK, pp. 75-122. 
Richardson, N., 1980. Species-specific aboveground shrub biomass in seral communities in three habitat types in west central Montana. Final Report. USDA Forest Service, Forestry Sciences Laboratory, Missoula, MT, 57 pp.

Roberts, M.R., Gilliam, F.S., 1995. Patterns and mechanisms of plant diversity in forested ecosystems: implications for forest management. Ecol. Appl. 5 (4), 969-977.

Romme, W.H., Knight, D.H., 1981. Fire frequency and subalpine forest succession along a topographic gradient in Wyoming. Ecology 62 (2), 319-326.

Ruben, J.A., Bolger, D.T., Peart, D.R., Ayres, M.P., 1999. Understory herb assemblages 25 and 60 years after clearcutting of a northern hardwood forest, USA. Biol. Conserv. 90, 203-215.

SAS Institute, Inc. 2001. JMP IN v. 4.0.4 (Academic). Duxbury Press, Belmont, CA.

Schoonmaker, P., McKee, A., 1988. Species composition and diversity during secondary succession of coniferous forests in the western Cascade Mountains of Oregon. For. Sci. 34 (4), 960-979.

Smith, W.K., Knapp, A.K., 1990. Ecophysiology of high elevation forests. In: Osmund, C.B., Ptelka, L.F., Hidy, G.M. (Eds.), Plant Biology of the Basin and Range. Springer, New York, pp. 87-142.

Sokal, R.R., Rohlf, F.J., 1981. Biometry, 2nd ed. Freeman, New York.

Stahelin, R., 1943. Factors influencing the natural restocking of high altitude burns by coniferous trees in the Central Rocky Mountains. Ecology 24 (1), 19-30.

Steele, R., Geier-Hayes, K., 1987. The grand fir/blue huckleberry habitat type in central Idaho: succession and management. USDA Forest Service General Technical Report No. INT-228.
Stein, W.I., 1995. Ten-year development of Douglas-fir and associated vegetation after different site preparation on Coast Range clearcuts. USDA Forest Service Research Paper No. PNW-473.

Stickney, P.F., 1990. Early development of vegetation following holocaustic fire in Northern Rocky Mountain forests. Northw. Sci. 64, 243-246.

Stransky, J.J., Juntley, J.C., Risner, W.J., 1986. Net community production dynamics in the herb-shrub stratum of a loblolly pine-hardwood forests: effects of clearcutting and site preparation. USDA Forest Service General Technical Report No. SO-61.

Tilman, D., Downing, J.A., 1994. Biodiversity and stability in grasslands. Nature 367, 363-365.

Turner, M.G., Romme, W.H., Gardner, R.H., Hargrove, W.W., 1997. Effects of fire size and pattern on early succession in Yellowstone National Park. Ecol. Monogr. 67 (4), 411-433.

Zager, P.E., 1980. The influence of logging and wildfire on grizzly bear habitat in northwestern Montana. Ph.D. Dissertation. University of Montana, Missoula, MT, $131 \mathrm{pp}$.

Zager, P.E., Jonkel, C., Habeck, J., 1983. Logging and wildfire influence on grizzly bear habitat in northwestern Montana. In: Meslow, E.C. (Ed.), Proceedings of the Fifth International Conference on Bear Research and Management, Madison, WI. International Association for Bear Research and Management, pp. 124-132.

Zimmerman, G.M., Goetz, H., Mielke, P.W.J.R., 1985. Use of an improved statistical method for group comparisons to study effects on prairie fire. Ecology 66, 606-611. 